\title{
Prognostic value of the type of onset of rheumatoid arthritis
}

\author{
R. LUUKKAINEN, H. ISOMÄKI, AND A. KAJANDER \\ From the Rheumatism Foundation Hospital, Heinola, Finland
}

SUMmARY The type of onset in 235 patients with rheumatoid arthritis (RA) was acute in 69, subacute in 55, and gradual in 111 patients. The radiological destruction of the hands and feet after 7 years from the beginning of the disease was the same in all patient groups. Thus the nature of the onset of RA seems not to have any significant influence on the outcome of the arthritis.

In recent handbooks ${ }^{12}$ the prognosis in rheumatoid arthritis is said to be better in patients with acute onset than in those with an insidious onset. However, a careful study of papers in this field does not necessarily support this concept. ${ }^{3-6}$ The following study was carried out to examine the matter further.

\section{Patients and methods}

In the years 1970 to 1973 a total of 293 patients with definite or classical RA at an early stage were treated at the Rheumatism Foundation Hospital, Heinola. Of these, 235 patients were investigated in 1978 for radiological destruction of the hands and feet after about 7 years from the beginning of the disease. ${ }^{7}$

The patients were divided into 3 groups according to the nature of the onset of arthritis. The onset was regarded as acute if it could be dated by the patient to a certain day, as subacute if it could be dated to within a week, and as gradual if it could be dated only to within a month.

Accepted for publication 22 April 1982.

Correspondence to $\operatorname{Dr}$ R. Luukkainen, Reumasäätiön Sairaala, SF-18120 Heinola 12, Finland.
Altogether 43 patients reported having had an infection within one month before the beginning of RA. Of these, 29 were respiratory tract infections, 8 tonsillitis, and 6 other infections.

Table 1 shows some of the characteristics of these groups at the early stage of the disease when the patients were admitted to hospital for the first time on account of the RA. Among the patients with an acute onset there were significantly $(p<0.02)$ more females and highly significantly more $(p<0.001)$ patients who had had an infection before the beginning of RA than among those with gradual onset.

The radiological progress of the joint destruction was measured according to the method of Larsen $e t$ $a l .{ }^{8}$ In this scale the stage of a normal joint is 0 and the stage of complete destruction 5 . The wrist, subtalar, II-V metacarpophalangeal, II-V metatarsophalangeal, and the interphalangeal joints of the thumbs and big toes were analysed. Of these joints a so-called general destruction index was calculated for each patient by adding the indices for the individual joints listed above and multiplying the indices for the subtalar and wrist joints by 5 . Thus the general joint index for a person with fully normal joints is 0 and for a person with totally destroyed joints it is 200 .

Table 1 Comparison of various groups

\begin{tabular}{|c|c|c|c|c|c|c|}
\hline & $\begin{array}{l}\text { Acute } \\
\text { onset }\end{array}$ & $S D$ & $\begin{array}{l}\text { Subacute } \\
\text { onset }\end{array}$ & $S D$ & $\begin{array}{l}\text { Gradual } \\
\text { onset }\end{array}$ & $S D$ \\
\hline No. of patients & 69 & & 55 & & 111 & \\
\hline Female (\%) & 84 & & 69 & & 68 & \\
\hline Seropositive (\%) & 71 & & 78 & & 82 & \\
\hline Mean age (years) & $40 \cdot 9$ & $11 \cdot 7$ & $41 \cdot 4$ & $10 \cdot 4$ & $40 \cdot 2$ & $11 \cdot 8$ \\
\hline Mean follow-up (months) & 87 & $22 \cdot 0$ & 86 & $17 \cdot 9$ & 91 & $18 \cdot 3$ \\
\hline Mean $\mathrm{Hb}$ & 118 & $13 \cdot 5$ & 121 & $14 \cdot 4$ & 126 & $14 \cdot 0$ \\
\hline \multirow{3}{*}{$\begin{array}{l}\text { Mean no. of ARA criteria } \\
\text { No. of patients with infection } \\
\text { before onset of RA }\end{array}$} & $6 \cdot 5$ & 0.83 & $6 \cdot 3$ & 0.84 & $6 \cdot 4$ & 0.78 \\
\hline & & & & & & \\
\hline & $23(33 \%)$ & & $10(18 \%)$ & & $10(9 \%)$ & \\
\hline
\end{tabular}

ESR $=$ erythrocyte sedimentation rate. $\quad \mathrm{Hb}=$ haemoglobin. $\quad$ ARA $=$ American Rheumatism Association. 
Table 2 Joint destruction in various groups after follow-up of 7 years.

\begin{tabular}{llll}
\hline & $\begin{array}{l}\text { Acute } \\
\text { onset }\end{array}$ & $\begin{array}{l}\text { Subacute } \\
\text { onset }\end{array}$ & $\begin{array}{l}\text { Gradual } \\
\text { onset }\end{array}$ \\
\hline $\begin{array}{l}\text { No of patients } \\
\text { Mean } x \text {-ray index }\end{array}$ & 69 & 55 & 111 \\
& $56 \cdot 1$ & $53 \cdot 6$ & $61 \cdot 2$ \\
\hline
\end{tabular}

\section{Results}

Table 2 shows the means of the $x$-ray index after the follow-up. In the group with an acute onset, it was on average $56 \cdot 1$, with a subacute onset $53 \cdot 6$, and with a gradual onset $61 \cdot 2$. These differences are not statistically significant.

In patients who had had a prior infection the deterioration of the $x$-ray index averaged $49 \cdot 5$, in the remaining patients it was $60 \cdot 3$. This difference is not statistically significant.

\section{Discussion}

The studies of Short and Bauer ${ }^{3}$ and of Duthie et al. ${ }^{4}$ show quite clearly that the prognosis is better in RA patients admitted to hospital within one year from the onset of the disease than in those admitted later. According to Short and Bauer $60 \%$ of patients with an acute onset and $51 \%$ with a gradual onset improved during the follow-up, but the authors did not regard this difference as important. The conceptions acute and gradual were not defined, and consequently they may not mean the same as acute and gradual in the present study.

The study of Duthie et al. ${ }^{4}$ shows that $53 \%$ of patients with a rapidly progressive course up to the time of admission were still after 9 years in functional grade I compared with $14 \%$ of those in whom the disease ran a more insidious course. All patients with a rapidly progressive course were admitted to hospital within one year compared with only $20 \%$ of the others. The authors regard a rapidly progressive course at the early stage as acute, and this also may have another meaning than acute in the present study.

In addition the concept of rheumatoid arthritis may have changed. The earlier studies probably included patients with, for example, incomplete Reiter's disease and reactive arthritis. In these diseases the onset is often acute and the prognosis better than in true rheumatoid arthritis. Short and Bauer's study also included patients with ankylosing spondylitis. ${ }^{3}$

Jacoby et al $^{5}{ }^{5}$ found no difference in prognosis between patients with acute, subacute, and gradual onset. In their study acute, subacute, and gradual onset had apparently the same meaning as in the present study. On the other hand in the study of Fleming et al. ${ }^{6}$ there was a trend towards poorer prognosis in patients with insidious onset. However, the trend was not very strong $(r=0 \cdot 192 ; p=0 \cdot 055)$. In this study the sudden, intermediate, and slow onset obviously had nearly the same meaning as acute, subacute, and gradual in the present study.

However, RA with an acute onset may induce the patient to contact a physician or a hospital sooner than one with a delayed onset. Early initiation of the treatment may play a part in remission in some patients and thus improve the prognosis.

In the present study a total of 43 patients had had an infection prior to the onset of the arthritis, mostly a respiratory tract infection $(67 \%)$. There is a clear accumulation of these patients in the group of acute onset; more than half of these ( 23 patients, $53 \%$ ) had an acute onset. Though these patients form a subgroup among all RA patients, the prognosis did not differ significantly from that of the other patients.

In conclusion, it can be stated that the type of onset of RA seems not to have any significant influence on the progress of radiological destruction of the hands and feet during a follow-up of 8 years.

\section{References}

1 Williams C J. Clinical picture of rhe umatoid arthritis. In: McCarty D J, ed. Arthritis and Allied Conditions. 9th ed. Philadelphia: Lea and Febiger, 1979: 467.

2 Harris E D. Rheumatoid arthritis. The clinical spectrum. In: Kelley W N, Harris D E, Ruddy S, Sledge C B, eds. Textbook of Rheumatology. Philadelphia: Saunders, 1981: 955.

3 Short LS, Bauer W. The course of rheumatoid arthritis in patients receiving simple medical and orthopedic measures. $N$ Engl J Med 1948; 238: 142-8.

4 Duthie J J R, Brown P E, Truelove L H, et al. Course and prognosis in rheumatoid arthritis. Ann Rheum Dis 1964; 18: $49-53$.

5 Jacoby R K, Jayson M I V, Cosh J A. Onset, early stages, and prognosis of rheumatoid arthritis: a clinical study of 100 patients with 11-year follow-up. $\mathrm{Br} M e d \mathrm{~J}$ 1973; ii: 96-100.

6 Fleming A, Crown J M, Corbett M. Early rheumatoid disease. I. Onset. Ann Rheum Dis 1976; 35: 357-60.

7 Luukkainen R. Chrysotherapy in rheumatoid arthritis. Scand $J$ Rheumatol 1980; (suppl 34): 22-4. :

8 Larsen A, Dale K, Eek M. Radiographic evaluation of rheumatoid arthritis and related conditions by standard reference films. Acta Radiol (Diagn) (Stokh) 1977; 18: 481-91. 